\title{
From Guild Artisans to Entrepreneurs: The Long Path of Italian Marble Mosaic and Terrazzo Craftsmen (16th c. Venice - 20th c. New York City)
}

\author{
Javier P. Grossutti \\ Researcher in Economic and Social History University of Padua, Department of \\ Historical and Geographic Sciences and the Ancient World
}

\begin{abstract}
Marble mosaic and terrazzo were a very common type of stone paving in Venice, Italy, especially between the sixteenth and eighteenth centuries. Throughout the period, migrant craftsmen from the nearby Alpine foothills area of Friuli (in northeastern Italy) virtually monopolized the Venetian marble mosaic and terrazzo trade. Thus, on February 9, 1583, the Venetian Council of Ten granted maestro (master) Sgualdo Sabadin from Friuli and his fellow Friulian workers of the arte dei terazzeri (art of terrazzo) the capacity to establish a school guild dedicated to St. Florian. The first chapters of the Mariegola de' Terazzeri (Statutes of the Terrazzo Workers Guild), which set the rules for the guild of terrazzo workers, was completed three years later, in September 1586.

From the 1830s onward, Friulian craftsmen began to export their skills and trade from Venice across Europe and later, at the turn of the twentieth century, overseas to several American cities. Prior to reaching America, mosaic and terrazzo workers left from their work places outside Italy, initially from Paris. Friulian mosaic and terrazzo workers were regarded as the "aristocracy" of the Italian American building workforce due to their highly specialized jobs: This contrasted with the bulk of Italians in the United States who were largely employed as unskilled. The New York marble mosaic- and terrazzopaving trade was completely in the hands of the Italian craftsmen, who demonstrated a strong tendency to become entrepreneurs. They made use of their craftsmanship comparative advantages to build a successful network of firms that dominated the domestic market, in a similar fashion to what had already been occurring in France, Germany, the United Kingdom, and other European countries.

This paper argues that immigrants can be powerful conduits for the transfer of skills and knowledge, and emphasizes the importance of studying skilled migrant artisan experiences. A closer look at ethnic migration flows reveals a variety of entrepreneurial experiences, even in groups largely considered unskilled. The Italian marble mosaic and terrazzo workers' experience sheds new light on ethnic entrepreneurship catering for the community as a whole, it reveals a remarkable long-lasting craftsmanship experience, thus demonstrating the successful continuity in business ownership and the passing down of craftsmanship knowledge across family generations. Creativity skills and innovative productive methods adopted by firms appear as a key factor that allowed these artisans to control the trade for such a long time.
\end{abstract}

International Labor and Working-Class History

No. 100, Fall 2021, pp. 60-86

(C) International Labor and Working-Class History, Inc., 2021. This is an Open Access article, distributed under the terms of the Creative Commons Attribution licence (http://creative commons.org/licenses/by/4.0/), which permits unrestricted re-use, distribution, and reproduction in any medium, provided the original work is properly cited.

doi:10.1017/S0147547920000253 


\section{Introduction}

This article refers to marble mosaic and terrazzo workers who came from a handful of villages in the Alpine foothill area of Friuli in northeastern Italy. Mosaics have traditionally been formed by hand-setting small pieces (known as tesserae) of stone, marble, ceramic, or glass in a decorative pattern applied to a surface that has been prepared with an adhesive. The word "terrazzo" is of Venetian origin, and the name is used broadly to designate almost any kind of interior flooring surface made from bits of marble or stone. Also known as pavimento alla veneziana (Venetian pavement) and seminato, terrazzo is a flooring in which chips of marble, stone or glass are scattered at random (literally, seminato is Italian for "sown") or arranged to form simple linear patterns or more elaborated figures on a lime and (later) cement matrix. On setting, the surface is ground smooth to show a cross section of the chips through the mixture.

At first, the marble mosaic and terrazzo artisans fulfilled the demands of the job market in Venice and the rest of northern Italy, then in France and the rest of Europe, and finally venturing overseas to countries like the United States, Canada, and Australia. The villages of origin of these craftsmen (initially Sequals and Solimbergo, later on, e.g., Fanna, Cavasso Nuovo, Arba, Spilimbergo), have never been the places where they carried on their trade. Prior to reaching the United States at the turn of the twentieth century, the majority of these artisans had experienced a period of work in mosaic and terrazzo trade in other European countries. In that respect, the marble mosaic and terrazzo workers from Friuli might be considered a group of artisans trained for labor markets situated outside of their places of origin. For many families this professional path, accomplished outside their villages of origin, lasted for centuries. Before a specialized school institutionalizing the local mosaic and terrazzo techniques was created in the early 1920s, it is worth noting that marble mosaic and terrazzo training was passed on from one generation to the next by means of family members and trusted apprentices in closely knit family-run businesses. ${ }^{1}$

This paper outlines the five-century-long migration trajectory and accumulated experience of a creative, skilled workforce as a continuum, regardless of the national (mainly Venice) or foreign destinations of these emigrant craftsmen. It focuses on a business network set up by a highly specialized group of emigrant artisans. The experience of marble mosaic and terrazzo workers from Friuli represents a striking experience in the history of Italian immigration to America: it is a paradigmatic example of the strong relationship between migration and trades, between particular districts and townships and particular occupations and migrant destinations.

This article is divided into six sections. The first introduces and discusses the early Venetian experience of mosaic and terrazzo workers from Friuli from the sixteenth century onward. It describes the height and the breaking up of the terrazzo guild system, which prompted a rapid de facto entrepreneurial process, materialized initially in Venice's mainland dominions, in northern Italy, 
and later in southern France, where many "Venetian" craftsmen settled in the early nineteenth century. The second section explores the arrival of mosaic and terrazzo workers from Friuli in the United States in the last decades of the nineteenth century: the presence of highly-skilled Italian mosaic and terrazzo workers (who were regarded as the aristocracy of the work force), contrasted with the more than two-thirds of the Italians arriving at the port of New York who were registered by the American authorities as either farm laborers or laborers. The third section focuses on the role of the renowned New York-based Herter Brothers decoration firm in the diffusion of the marble mosaic flooring on a large scale: All the mosaicists that were employed by the company were Italians. However, as the trade expanded in the last two decades of the nineteenth century, so did the network of the marble mosaic firms, the majority of which were owned by Italian craftsmen who had worked in the Herter Brothers' mosaic department. The fourth section traces the pathway that drove the New York-Italian marble mosaic masters to unionize successfully in 1888: They were the first Italian building-trade workers to establish a trade union. Despite the initial socialist orientation of these skilled artisans, their success as business owners eclipsed their enthusiasm for unionism. The widespread popularity and acclaim for terrazzo from early on in the 1920s, which soon overtook marble mosaic in popularity and came close to becoming a ubiquitous flooring material for public buildings and apartment buildings, is discussed in section five. The following section delves into the creation of the mosaic and terrazzo contractor association in 1924. By then, Italian and Italian American mosaic and terrazzo entrepreneurs had built a powerful network of firms that dominated the market across North America. The concluding section stresses the marble mosaic and terrazzo migration as a longlasting craftsmanship experience, buttressed by self-employment, organizational, and creative attitudes of the artisans who came from a handful of villages in northeastern Italy.

Whereas attention has been given to the more numerous, less-skilled emigrants, this article purposely focuses its attention on the importance of studying skilled migrant artisan experiences, which are often overlooked by scholars. Yet recent research on craftworkers, such as Welsh tinplate workers, Belgian glass workers, and British shipbuilders, ${ }^{2}$ offers good examples of the considerable role played by skilled immigrants in the development of American industry.

\section{Mosaic and terrazzo workers: from late sixteenth century Venice to early nineteenth century France}

In the first few decades of the sixteenth century, Rome and Venice both gave a new lease on life to their local mosaic schools. ${ }^{3}$ In the Lagoon city, skillful master mosaic workers (for example, the Zuccato and Bianchini families, Bartolomeo Bozza, Lorenzo Ceccato) developed unique techniques of mosaic production, which allowed them to translate into mosaic the fine details of paintings made 
by masters such as Titian, Raphael, Salviati, Tintoretto, and Sansovino. ${ }^{4}$ At the time, some mosaic workers from Friuli, such as the Bianchini family, were chiefly engaged in the restoration and execution of the mosaics in St. Mark's Cathedral. Between 1517 and the early 1580s, the brothers Domenico and Vincenzo Bianchini and his son, Gian Antonio (presumably from the small village of Solimbergo), executed many of the mosaics in St. Mark's Cathedral, namely the Judgment of Solomon and the marvelous Tree of Jesse. ${ }^{5}$

The first Venetian terrazzo floorings also dated back to the sixteenth century: they consisted of very simple archetypes and were executed by workers from Friuli. ${ }^{6}$ On February 9, 1583, the Venetian Council of Ten granted maestro (master) Sgualdo Sabadin (or Sabadini) from Provesano (Friuli) and his fellow Friulian workers of the arte dei terazzeri (art of terrazzo) the capacity to establish a school dedicated to St. Florian. ${ }^{7}$ Other master members of the terrazzo guild were Zuanne Roiter from Barbeano, Piero Pangon and Battista Crovat [Crovatto] from Sequals, Nicolò Sabadin from Provesano, Bortolomio de Mazzuoli [Mazziol/i] from Solimbergo, and Bernardo de Ceser from Fanna. ${ }^{8}$ It is not clear if the school was simply a devotional confraternity or whether it was conceived as an institution created for an autonomous art. Regardless, the first chapters of the Mariegola de' Terazzeri (Statutes of the Terrazzo Workers Guild), which set the rules for the guild of terrazzo workers, was completed only three years later in September $1586 .{ }^{9}$ The creation of a guild entailed the replacement of isolated artisans with teams of organized workers that had to strictly conform to societal and professional rules. The art and professional guild statutes went to great lengths to preserve an equilibrium within the individual branches of the labor force. ${ }^{10}$ The terazzeri, as terrazzo workers were then called, were regarded as true artists who had prudently handed the secrets of their craft down from father to son. ${ }^{11}$ For outsiders, the training path to become a maestro terazzer (terrazzo master) was firmly fixed and demanding: candidates were allowed to register for the master exam only after a seven-year-training period as an apprentice (garzone/apprendista) and a three-year-period as an assistant (lavorante).

Between 1669 and 1688, Venice experienced a building boom that, although sluggish at times, continued until the 1760s. Over this period an estimated forty buildings and churches, a dozen theatres, at least a half dozen hospitals, and a dozen schools were built in Venice. ${ }^{12}$ In the first few decades of the eighteenth century, the number of terrazzo masters and apprentices rose significantly (also due to the seasonal influx of workforce in the assistant ranks coming from the mainland), despite the fluctuating Venetian building market, which could not guarantee job opportunities to all terrazzo artisans. Many of these workers were immigrants. In fact, the art of terrazzo was dominated by craftsmen from the Alpine foothill areas of Friuli. Pellarin, Crovatto, Carnera, Mazzioli, Cristofoli, Odorico, Del Turco, Foscato, Mora, Mander, Patrizio, and Pasquali from Sequals and Solimbergo were the most widespread surnames among the terrazzo (and marble mosaic flooring) masters in late seventeenth and early eighteenth century Venice. ${ }^{13}$ 
Many of these "Venetian" terrazzo masters (and apprentices), after having executed terrazzo in cities of the Venetian mainland, such as Padua, Vicenza, Treviso, Este, Bassano, and in other northern Italian cities like Genoa, decided to establish their businesses in these centers. ${ }^{14}$ The years that precede and follow the downfall of the Venetian Republic (1797) were marked by political instability, social crisis, and economic recession, which caused widespread unemployment and led to the overwhelming impoverishment of the inhabitants, a sharp drop in the number of city dwellers in the old town center (from 160,000 to 100,000 in just a few years), and the significant fall in the value of real estate. The building market came to a near standstill, and even the renovation of homes slowed down significantly. The city of Venice offered insufficient opportunities to satisfy the demand of assistants, apprentices, and terrazzo masters. The breaking up of the guild system, set forth officially in 1807, and the relaxation of the terrazzo workers' group solidarity prompted a rapid de facto entrepreneurial process. While terrazzo masters, who possessed the talent, the skills, the tools, and the necessary assets, transformed themselves into entrepreneurs, apprentices and assistants were only too willing to offer their labor to the former. ${ }^{15}$

In the early nineteenth century, the discovery of antique mosaics in southern France drew some Friulian terrazzo masters, who moved from Venice to the other side of the Alps to restore the Roman and medieval masterpieces that had been discovered. ${ }^{16}$ The terrazzo and mosaic artisan Angelo Giovanni Battista Mora, from Sequals, settled in Lyon as early as 1829/1830, and established a marble mosaic company, initially devoted to the restoration of the ancient mosaics in the city. The Entreprise Mora, later run by Angelo's sons Edoardo and Pietro, is considered one of the first firms founded by an Italian mosaic craftsman in France. ${ }^{17}$ Angelo Giovanni Battista Mora had been living in Venice before moving to France. In the years that followed Mora's move to France, many of Mora's fellow countrymen living in Venice had relocated to other French cities, such as Nîmes, Montpellier, Narbonne, Béziers, Orange, and Avignon, to bring to light and restore marble mosaic floors.

Gian Domenico Facchina, who was born in Sequals in 1826, is the master craftsman and entrepreneur that deserves credit for relaunching marble mosaic in France and then in the rest of Europe and overseas. At an early age Facchina joined a relative in Trieste, where he attended a school of design. In this period he worked as an assistant in restoring the mosaics at the local cathedral of Saint Giusto. Captivated by mosaics, Facchina decided to move to Venice, where his uncle Giuseppe, a cleric at St. Mark's Cathedral, introduced him to some local mosaic masters for whom Facchina worked as an apprentice. Around 1847, he moved to southwestern France, where he and many of his fellow craftsmen countrymen were involved in the restoration of the recently discovered antique mosaics. Three years later, in 1850, Facchina established his own mosaic company, and in 1858 he patented a "method of detaching ancient mosaics and relaying them without altering their design" (système d'extraction et pose sans alteration des mosaïques antiques). This technique led to the so called "indirect method," which made it possible to produce 
mosaics on what was virtually an industrial scale. ${ }^{18}$ The work, which was executed in the studio, entailed setting the tesserae upside down on a temporary paper base. The mosaic was then shipped to its destination and installed in situ (both to walls and floors). This technique of prefabrication, probably used as early as the Greco-Roman age, was a cheaper method of producing mosaic and was devised in order to meet the demands of the new scale of production. In addition to this, the "indirect method" does not require the designer, the maker, the layer, and the polisher of the mosaic to be the same person, increasing labor division within the trade: Italian craftsmen were only responsible for the making and, above all, the laying and the polishing of the mosaics. By using this technique, Facchina together with the firms of his fellow countrymen Cristofoli, Mazzioli, and Del Turco (all from Sequals), had successfully installed mosaics in Charles Garnier's Paris Opera House in 1866. For the first time in France, this Friulian craftsman introduced decorative mosaic in a public building, as architect Garnier himself declared and an inscription in Greek characters stated inside the Opera. ${ }^{19}$

They "have brought a special training, a traditional aptitude:" Italian mosaic and terrazzo workers in America at the turn of the century

From the end of the nineteenth century, Italian emigration exhibited marked regional characteristics. Relatively small numbers departed from the central regions of Italy, while from the north, particularly from Veneto, Friuli, Lombardy, Liguria, and Piedmont, emigration took on vast proportions, continuing in part along its seasonal trans-Alpine emigrant paths, but also, significantly, propelling hundreds of thousands of emigrants to Argentina and Brazil where most of them permanently settled. At the turn of the twentieth century, the southern regions, foremost Campania, Calabria, Abruzzi and Molise, Basilicata, and Sicily, began to register high rates of departures, primarily to the United States. ${ }^{20}$

From the 1880s to the outbreak of World War I, Friuli represented "the greatest single source of Italian emigrants, where the élite of the population came increasingly to think in terms of temporary migration," commented Frank Thistlethwaite. ${ }^{21}$ "The skilled workmen of Udine," observed Robert F. Foerster in his classic and, to some extent, unexcelled early work on Italian emigration, "have been able to labor [temporary] abroad upon terms acceptable to their employers and themselves and have found it cheapest to spend the winter in their natal country; they have done better than their agricultural brethren. That is why, counting upon future employment in neighboring countries, the children of Friuli have been trained to the more skilled non-agricultural occupations." 22 The mystifying fact, added Foerster, is that "in the temporary emigration from [the] Friuli [between the last decades of the nineteenth century and the outbreak of World War I] these more or less skilled workmen, far from being occasional, are a very great part of the emigrants and often indeed the élite of the population." 23 According to Foerster "What is remarkable in this 
story is hardly that boys are trained with reference to work in other lands, but rather that as a result of such training a population should grow up which absolutely depended for its livelihood upon employment abroad." ${ }^{24}$ Thus, the way to approach the study of a group of emigrants who traditionally and continuously earn a living by drawing from work in a foreign labor market (as in the case of workers of Friuli and some other Italian Alpine villages) needs to be different vis-a-vis other emigrants whose departure is in response to the call of a foreign country at a certain point in time. It is likely that, over the time, the first group developed an array of trades (which became their stable occupation) required by the foreign labor market, while the second group tried to rapidly adjust to the labor needs in their host nation.

The outstanding arrival of Italians to the United States in the last decades of the nineteenth century corresponded with a major transformation in the traditional American sources of immigration. Prior to the 1890s, the great majority of Europeans reaching the United States were British, Irish, German, and Scandinavian. From the 1890s on, the sources for these flows moved eastward and southward. This "new immigration" was composed predominantly of Slavs, Jews, and Italians. ${ }^{25}$ Growing steadily from the 1880 s onward (in the latter part of the nineteenth century, the United states welcomed about eight hundred thousand Italians), the influx of immigrants from Italy reached mass proportions after 1900. In the first fifteen years of the century, over three million Italians entered the United States. They constituted the largest nationality of the "new immigration" and over 20 percent of the total immigration of this period.

The main characteristics of Italian emigration to America were apparent. These migrants were largely from southern Italy, were increasingly inclined to return to Europe after working as laborers on railway construction, in mines, and in construction sites, had taken on a variety of mostly unskilled occupations in the United States, and had developed the institution of the padrone system. ${ }^{26}$ However, some villages in northern Italy also distinguished themselves in particular as areas of departure for America. In 1902, the US Industrial Commission included Udine (the capital of Friuli) and the nearby area as "collecting points" and "contributing districts" of European emigration to the United States. ${ }^{27}$ The map prepared by the US Industrial Commission depicted Italy as a country where much of the emigrants to America came from the Southern regions (Puglia and some areas in Sicily excluded). In the northern part of the country, a high number of migrants left from Friuli as well. The route followed by emigrants took them from Udine to New York City via the railroad routes of Milan, Turin, Modane, Basel, and Paris, and the French ports of Havre and Cherbourg.

At the turn of the twentieth century, over two-thirds of the Italians arriving at the port of New York were registered by the American authorities as either farm laborers or laborers. A minority of the immigrants, less than 15 to 20 percent, were artisans. ${ }^{28}$ By 1893 , the Italians constituted three quarters of the building laborers in the city of New York: "Thousands more entered the 
country in the next twenty years." 29 According to data from the Immigration Commission, between 1899 and 1910, about three quarters of the Italian immigrants reporting occupations (296,662 Northern Italians, 1,471,659 Southern Italians) were farmers; in the same period skilled immigrants represented 20.4 percent (around 60,500 workers) of those from Northern Italy reporting occupations, and 14.6 percent $(214,800)$ of those from Southern Italy. ${ }^{30}$ In 1900 , about half of the Italian men in the United States were employed as unskilled laborers, and this percentage did not change much before World War I.

Italians were excluded from higher-paying and better jobs not only because of the language barrier and lack of skills but because of the racial prejudice against them. In fact, even educated and skilled immigrants were often compelled to take up the pick and shovel, further reinforcing the stereotype of the Italians as nothing but unskilled workmen. ${ }^{31}$ That was not the case with Italian mosaic and terrazzo workers from Friuli. Because their work was so highly specialized and well paid, they were regarded as the aristocracy of the Italian work force. In 1893, Frederick L. Matthes, a construction engineer interviewed by the Real Estate Record and Builders Guide magazine, declared that "as a rule the Italian laborer does not advance in building; some indeed, learn the various trades, but are at best only rough workmen, not at all fitted for fine work. There are exceptions though in some branches. Take mosaic work: where can you find any class who will surpass the Italian? They monopolize the business too." 32

The presence of this group within the huge building sector came to the attention of both American authorities and attentive scholars of Italian emigration in the United States. In 1902, the Industrial Commission stated that, among the Italian population, whereas "skilled workmen from the north of Italy in large numbers go directly to the interior [of the state of New York] as marble-cutters, miners, mill hands, etc. . some 2,000 workers in marble and mosaic, and many mechanics, masons, stonecutters, bricklayers, carpenters, and cabinet-makers" had remained in New York City. ${ }^{33}$ Robert F. Foerster wrote that the expertise and competence of skilled Italian building-trades workmen, who appear to have an outstanding importance in the statistics of disembarking aliens, were:

easily adapted to the circumstances of the country, and sometimes it is of a superior order, and is prized. From Venetia and Tuscany, for example, workers in mosaics and stucco [respectively] have brought a special training, a traditional aptitude of which Americans have been glad to avail themselves [...] It is common to find them at work on the most exacting tasks, ensuring the neatness of appearance, or the beauty, of the most ambitious public and private structures. ${ }^{34}$

The first Friulian mosaicists, Domenico Pasquali and a fellow countryman (whose name has been lost), both from Sequals, came to the United States in 1870. Some years later, according to William Henry Burke, the owner of one of the first London-based mosaic firms, ${ }^{35}$ they were engaged by the Herter Brothers company to lay mosaic floors in the New York City homes of Jay 
Gould and Darius Ogden Mills. Domenico Pasquali and his fellow countryman subsequently laid mosaic flooring in the hallways of several small residences in New York and Boston, but after a short stay and due to their lack of success, they left the United States for an unknown destination in South America. ${ }^{36}$ Interestingly, Domenico Pasquali came to the United States from Liverpool, and not from the more common emigration ports of Havre or Cherbourg. This, and the fact that Burke explicitly mentioned Pasquali in his story of marble mosaic pavements, might suggest that the former might have worked for the Burke company in London prior to his arrival in New York. ${ }^{37}$ In fact, from the 1880s to the beginning of World War I, almost all the Italian marble mosaic and terrazzo artisans who reached the United States had started their careers in France, Germany, Austria, Switzerland, and Great Britain where they had worked for companies ordinarily owned by their fellow countrymen, from whom they also learnt the trade. This was not only the case of the aforementioned Domenico Pasquali, and the mosaic workers hired by the Herter Brothers firm, but also of many of the artisans whose names were recorded in The Art of Mosaic and Terrazzo magazine.

The patterns that led emigrants from Europe to the United States appear to be clear. "The immigrant in the United States in a large measure assists as well as advises his friends in the Old World to emigrate," stated the Immigration Commission in 1911: ${ }^{38}$ Emigration from Europe proceeded "according to welldefined individual plans rather than in a haphazard way" added the Immigration Commission. ${ }^{39}$ This emigration path applied also to marble mosaic and terrazzo workers. In view of the fact that these artisans continued to be involved in the same trade on either side of the Atlantic, marble mosaic and terrazzo workers preferred the American market over the French, German, Swiss, Austrian, or British ones because they considered the former to offer more immediate economic earnings and better perspectives for future upgrades than the latter. It is clear, as pointed out by Thistlethwaite referring to skilled emigrants, that: "The connection between migration and a trade was often close, and it was, moreover, already well established in Europe before the attraction of America began to be felt." 40

"Any competent mechanic with a little money and experience could set up a shop as a contractor:" The Herter Brothers and the network of the New York marble mosaic firms

The renowned New York-based Herter Brothers decoration firm, which was established by the German-born brothers Gustave and Christian, was the first in the United States to execute marble mosaic floors on a large scale, which were carried out by Friulian craftsmen who had previously worked in Paris. In 1879, Christian Herter began the most elaborate commission of his career, the William H. Vanderbilt residence in New York City on Fifth Avenue at Fifty-First Street. Six to seven hundred craftsmen, some imported from Europe, worked to complete the elaborate decoration of the building by January $1882 .^{41}$ The mosaic work had been assigned to the company Maison 
Facchina Mosaïques en Marbre of Paris, owned by Gian Domenico Facchina. In 1880, mosaic masters Luigi Zampolino from Spilimbergo and Filippo Crovato from Sequals were sent by Facchina to execute colored-glass mosaics on the ceilings and marble mosaic on the floors in the vestibule of William H. Vanderbilt's residence. ${ }^{42}$ Soon after, in 1881 , the Herter Brothers firm organized a department solely for mosaics, and thereafter carried out a considerable amount of work in New York and in various parts of the United States. While German workers represented the majority of the artisans in the Herter Brothers' cabinet-maker department, all the mosaicists that were engaged by the company were Italians. ${ }^{43}$ The working hierarchy, at least for the last few years of operation of the company's mosaic department, was clear: while mosaic masters (mechanics) were almost entirely from Friuli (Luigi Zampolino was in charge of the mosaic department from 1880 to the company's closure in 1907), assistants (helpers, polishers, and marble cutters) mostly came from other Italian regions. ${ }^{44}$ Eventually, most of the former (the mechanics) established their own company. According to Grace Palladino, in those days: "Any competent mechanic with a little money and experience could set up a shop as a contractor." 45 The building industry was organized according to a (sub)contracting system, and most of the marble mosaic and terrazzo firms and co-operatives followed this scheme: "The mason builder, or general contractor, secures the contract from the owner, or 'client', and generally puts up the brickwork; but he submits by competing bidding all the other work to as many contractors as there are kinds of work." 46 Sub-contractors supplied both equipment and skilled men in their specialty. The padrone system never distinguished the work relationship within the mosaic and terrazzo trade, because the main feature on which it was based (the padrone was a middleman who stood between the contractor and the worker) was absent.

Herter Brothers mosaic workers were responsible for the gem-like mosaic decoration of many of New York's most famous buildings, such as the palatial homes of the Goulds and the Villards, the ceilings of the dome of the Metropolitan Life Insurance Company Building, the Metropolitan Club, the Morgan Library, and the New York Historical Society. Italian mosaicists who worked for Herter Brothers executed mosaics in many other buildings all over the United States, embellishing the Boston Public Library and the opulent residences of Chicago barons such as George Mortimer Pullman, Philip Danforth Armour, and Potter Palmer. ${ }^{47}$

Simultaneously many other mosaic workers established their own companies. In 1890, The Art Amateur journal of New York stated that while

mosaics were practically unknown here when Mr. W.H. Vanderbilt brought over from Paris two workmen to assist in decorating his new house on Fifth Avenue, today there are eight firms in New York City alone which make mosaics the whole or a part of their business, giving employment to fifty mosaic workers and double that number to helpers and masons. ${ }^{48}$ 
The journal added that

one of the most famous house-decorating firms in this city [surely a reference to the Herter Brothers] has enough orders on hand to keep its mosaic workers busy for a year to come, and another firm has over fifty specimens of its work in residences, churches, banks, theatres, and other public buildings in this city, besides having a generous patronage in the East, West, North, and South, so rapidly has the industry developed." 49

The Art Amateur journal most probably referred to the "Pellarin \& Co. Roman and Venetian Marble Mosaic and Terrazzo" owned by Vincenzo (Vincent) Pellarin from Sequals. The firm was initially established by Giuseppe (Joseph) Pasquali of Sequals, yet another of the pioneers of the diffusion of the mosaic trade in America. Pasquali, who had practiced the craft in Austria and Switzerland, came to New York in 1881. In a few months, he had associated himself with the Swiss Charles Aeschlimann and founded the house "J. Pasquali \& C. Aeschlimann - Manufacturers of Roman and Venetian Marble Mosaics." In October 1886, Joseph Pasquali retired, and Charles Aeschlimann and Vincent Pellarin became business partners, changing the firm's name to "Aeschlimann \& Pellarin." ${ }^{50}$ In June 1898, Vincent Pellarin, who prior to coming to New York also worked for Gian Domenico Facchina in Paris, became the sole owner of the company. ${ }^{51}$

During the same period, other mosaic firms owned by Italians operated in the New York building industry. Vittorio (Victor) Foscato from Sequals, who, prior to coming to New York, worked in Manchester, England, was the proprietor of "V. Foscato Inc.," while Luigi De Paoli from Istrago (Spilimbergo) established the "De Paoli Company, Inc." with his brothers Vincenzo and Alessandro, first in New York, then in Boston. Likewise, many Italian mosaicists worked cooperatively, as was common in Europe among Friulian mosaic and terrazzo workers. In 1889, Luigi (Louis) Pasquali, from Sequals, was instrumental in organizing a group of fellow artisans into a company that became known as the "Marble \& Enamel Mosaic Co-operative Co."52

Marble mosaic firms in America employed the "indirect method" developed by Facchina, which allowed companies to complete mosaic in the shop and then deliver it to the job ready for installation: "Few people seem to know that the designs are first laid out on full-sized drawings, the little chips being glued to the paper, and then the entire pattern laid upon the wall, floor or ceiling in sections" according to an article published in the Worcester Daily Spy on March 31, $1889 .{ }^{53}$ The article described the momentum gained by mosaic: "Mosaics are decidedly the architectural fad of the day - mosaic floors and ceilings, mosaic walls and mantels, mosaic pictures, mosaic everything [...] The growth and multiplication of the art seem wonderfully rapid. Every architect gets it into every new plan he makes." 54 At the turn of the twentieth century, American observers became aware of "the progress this [mosaic] art had made in the United States and the wide diversity of its application in the 
decoration of the modern buildings of today," as stated in The New York Times on March 13, 1897. The article predicted the large spread of mosaic in the coming years stating that it "is bound to enter more and more into the plans of architects, for beyond its possibilities for artistic decoration, its durability commends it." The growth in the use of marble mosaic in American buildings from 1880s onward resulted largely from the rise of Beaux-Arts architecture throughout the country. The works of the American Beaux-Arts architects, and even of some decorators who got acquainted with the most fashionable European styles and who collaborated with artists and craftsmen, played a great lead in the consolidation of the movement. ${ }^{55}$ The Herter Brothers experience epitomized the role of a decorator's firm, which drew from the French Second Empire architecture the best elements of design. Christian Herter sojourned extensively in Paris, where he "must have followed the progress of Charles Garnier's Opera, the most significant edifice built during the Second Empire."56 Thus, the importance of the Herters in the spread of marble mosaic is apparent.

\section{An exclusively Venetian organization: Marble mosaic and terrazzo mechanics} and helpers unionized

In the United States, the process that leads mosaic and terrazzo mechanics (masters) and helpers to unionize was different for each group, not only because the tasks performed by each were different but also due to the diverse bargaining power of mechanics and helpers. According to the US Department of Labor, mechanics in marble mosaic and terrazzo work (who unionized first) were in charge of "marble mosaic, venetian enamel, and terrazzo, the cutting and assembling of art ceramic, glass mosaic, and the casting of all terrazzo in shops and mills." 57 Mechanics were also responsible for "all bedding above concrete floors or walls, that preparation, laying, or setting of the metal or wooden strips and grounds, where mosaic and terrazzo is to be applied." Terrazzo helpers, for their part, managed "all the handling of sand, cement, lime, terrazzo, and all other materials that may be used by the marble, mosaic, and terrazzo workers after being delivered at the building, or at the shop; rubbing and cleaning all marble, mosaic, and terrazzo floors, bare wainscoting when run on the building by hand or machine." 58

The capacity and desire of the Italian mosaic and terrazzo workers to organize themselves was apparent soon after their arrival in the United States. In 1888, Italian marble mosaicists in New York created the Italian Mosaic Marble Workers union, later renamed the Mosaic and Terrazzo Workers Association of New York \& Vicinity. They were the first Italian building trade workers to unionize successfully in the United States. ${ }^{59}$ Union membership consisted of the most expert marble mosaic and then terrazzo workers, the so-called mechanics. The fact that mosaic and terrazzo mechanics "had a skill which their employers could not replace helps to explain the early success of the union movement among them." 60 Their expertise gave them a monopoly, so that they completely controlled the mosaic and terrazzo industry in New York 
without the support of a national union, "although they were forced to maintain friendly relation with other building trades' workers who could have refused to work on a job where they were employed." ${ }^{61}$ Since the marble mosaic and terrazzo execution process was done largely by hand, technological changes in building trades (e.g., the shift from masonry to structural steel construction between the 1880 s and 1890 s) ${ }^{62}$ did not affect the mosaic and terrazzo mechanics' union bargaining power. The adoption of machinery (electric grinding and polishing machine) did not hinder the powerful position of the mechanic union either, since the polishing was performed by the helpers.

One year after the establishment of the mosaic union, the Central Labor Federation of New York - made up almost entirely of delegates from unions that were socialist or affiliated with the Socialist Labor Party-accepted credentials from the mechanics of the Italian Mosaic Marble Workers. ${ }^{63}$ Soon after, in 1890, marble mosaic assistants created the Italian Mosaic Marble Workers Helpers union, later known as the Mosaic Terrazzo Helpers Association of New York \& Vicinity. No marble mosaic union existed in America before the creation of the Italian Mosaic Marble Workers and the Italian Mosaic Marble Workers Helpers unions. Nearly all of the mosaic workers, both mechanics and helpers, in the city were Italians.

The baptism by fire for the marble mosaic union was probably the strike of New York building industries in April 1890. The mechanics of the marble mosaic union demanded nine hours and $\$ 3.50$ a day, with eight hours on Saturdays. Herter Brothers' marble mosaic and terrazzo workers received remarkable support from their German cabinet-maker fellows, who embarked on a sympathetic strike: "All the cabinetmakers, varnishers and painters employed in the Herter Brothers factory, at Twenty-eight St. and First Ave., went on strike yesterday in sympathy with the Italian marble mosaic workers, who have been on strike for two weeks," stated the New York Tribune on May 3, 1890. In October 1890, the Workmen's Advocate, the official journal of The Socialist Labor Party, reported that the mechanics of the Italian Mosaic Marble Workers union had unanimously resolved "to send delegates to the Socialist Labor Party Convention for political action." "64 In September 1891, the Italian Mosaic Marble Workers union participated in New York City's Labor Day Parade, as part of the nearly 9,000 men in a line that ran from Union Square to Washington Square. ${ }^{65}$ The mosaic and terrazzo mechanics' and helpers' unions, however, showed little involvement in the Central Labor Federation. They twice lost their seats for non-attendance at meetings. The seats of delegates Egidio Marchesini from the mechanic's union and of B. Binaghi, Pompeo Spagnuolo, and Endredi Cuneo from the helpers' union were declared vacant in April and November 1892. ${ }^{66}$

"Despite its socialist orientation, the [mechanics of the] Italian Marble and Mosaic Workers' Union began to exhibit some of the characteristics of conservative craft unionism. It closed its ranks to many men who wished to become members and once became involved in open violence with members of the Italian Marble and Mosaic Workers' Helpers, who demanded the right to join 
the parent union," observed Edwin Fenton. ${ }^{67}$ The helpers' union accused the mechanics' union of having "made that union an exclusively Venetian organization. If a helper learns the trade of mosaic laying and applies for admission to that union, he is not taken in unless he happens to come from Venice." 68 The success of these skilled artisans as business owners eclipsed their enthusiasm for unionism. The work experience of the Friulian mosaic worker Anthony (Antonio) Tramontin, for example, epitomizes the path from unionism to entrepreneurship. In 1897, seven years after his arrival in the United States, Tramontin was a member of the board of the Building Trades Association of New York, representing the mechanics of the Marble Mosaic Workers union. In 1900, he left the city for Philadelphia where he established a small mosaic company; later on he joined forces with a fellow countryman of the Cassini Mosaic and Tile Co. of Cincinnati, and in 1922, he established the Tramontin Brothers firm in Detroit in partnership with his brother. At the National Terrazzo and Mosaic Association (NTMA) sixth annual convention held in Detroit in 1935, Tramontin was elected president of the contractor's organization. This trajectory was common to many other mosaic and terrazzo entrepreneurs. ${ }^{69}$

In 1893, the unionized marble mosaic mechanics and helpers in New York City counted as many as four hundred members. ${ }^{70}$ In 1896 the Italian Marble Mosaic Workers Helpers' Union hit seven hundred members, while the mechanics of the Italian Marble and Mosaic Workers' Association membership had about one thousand. ${ }^{71}$ The common ethnicity shared by marble mosaic and terrazzo workers and entrepreneurs did not always secure worker's loyalty and vice-versa. From October 1, 1903, to December 31, 1909, the grievances filed by the mosaic and terrazzo mechanics' union amounted to twenty-one (sixteen of which were referred to arbitration, fifteen were decided favorably to the union, and one was decided adversely), while those filed by the mosaic worker's helpers total only two. ${ }^{72}$ The grievances and complaints had surely contributed to improve conditions and wages of mosaic and terrazzo mechanics in New York City, which soared from a minimum daily (eight hours constituted a day's work, four hours on Saturday, for forty-four hours per week) rate of $\$ 4.00$ in 1906 to $\$ 4.25$ in 1907 , and $\$ 4.50$ in 1914; mosaic worker's helpers rose from $\$ 2.50$ in 1906 to $\$ 2.75$ in 1907 , and $\$ 3.00$ in 1914 . In 1914 , the daily wage rate for bricklayers and marble carvers amounted to $\$ 6.00, \$ 5.50$ for marble cutters and setters, $\$ 3.25$ for marble cutters and setters' helpers, $\$ 4.00$ for marble polishers, $\$ 4.25$ for marble sawyers, $\$ 5.50$ for tile layers, $\$ 3.38$ for tile layers' helpers, and $\$ 3.00$ for hod carriers. ${ }^{73}$

In November 1919, the Bricklayers, Masons, and Plasterers' International Union of America (BMPIU) granted a Charter to the mechanics of the mosaic and terrazzo union, which became Union No. 3 of New York City. A mosaic and terrazzo mechanic was paid $\$ 0.75$ cents per hour. ${ }^{74}$ The union's business agent, Federico G. Patrizio (Frederick J. Patrizio), who was born in Sequals in 1889, and came to the United States at the age of fourteen, was instrumental in successfully affiliating the union with the BMPIU. In the early 1920s, the Italian Mosaic Marble Workers Helpers joined, instead, the International 
Association of Marble, Stone and Slate Polishers, Rubbers, and Sawyers, Tile and Marble Setters' Helpers. In the 1920s and 1930s, the mechanics of the Mosaic and Terrazzo Workers' union counted 180 members. All of them were Italian and nearly all of them were from Friuli: the minutes of the meetings were written both in Italian and English. ${ }^{75}$

In New York City, during the 1880s and 1890s, and even in the 1920s and 1930s, many of these Italian marble mosaic and terrazzo workers lived in the Eighteenth and Twenty-first Wards, in the area between First and Third Avenues bounded by East Twenty-fourth Street to the south and East Thirtysixth Street to the north. ${ }^{76}$ They lived in the same area where the Herter Brothers factory was located, on 479-85 First Avenue near East Twentyeighth Street. Thus for marble mosaic and terrazzo workers, their choice of residence soon after their arrival in New York City was subject to craft rather than ethnicity. In fact, when the first groups of Italian marble mosaic and terrazzo workers arrived in the city in 1880 s and 1890 s, they did not cluster with the majority of Italians in lower Manhattan (where Italians immigrants had moved into the old Irish section and fashioned a Little Italy west of the Bowery in the Sixth and Fourteenth Wards), in the Fourth, the Eight, and the Ninth Wards, and in Harlem. In the Eighteenth and Twenty-first Wards Italian mosaic and terrazzo workers initially mingled randomly with Americans and other Europeans. In the area of East Twenty-fifth and East Twenty-sixth Streets bounded by First and Third Avenues, for example, Italian mosaic and terrazzo workers gathered with Irish, German, Swedish, English, Swiss, and Bohemian people, and with Russian and Polish Jews.

Italian marble mosaic and terrazzo workers who arrived in the early 1900s and during the interwar period joined their craftsmen fellow countrymen who resided in the Eighteenth and Twenty-first Wards. By this time, however, the area drew also emigrants from Friuli not involved in the mosaic and terrazzo trade. For Friulians, the choice about where to dwell in New York City now depended on ethnicity. In the 1920s and 1930s, the area progressively became less multi-ethnic than it was at the turn of the century and adopted a rather homogeneous Italian aspect becoming a sort of Friulian enclave. These families experienced a powerful sense of community, which comes from a shared provenance, and from the practice of a common craft by many of the male workers. The majority of these craftsmen lived with their families (wives and children), which they generally brought to the United States some years after their own arrival. Indeed, the mosaic and terrazzo workers migration to New York overwhelmingly became a definitive journey, and further movements (mostly in search of new labor markets and opportunities) involved internal (to the midwestern, southern, and western states) rather than external (directed abroad) displacements.

The decline of marble mosaic and the spread of terrazzo in the 1920s and 1930s

The first terrazzo floors were laid in the United States in the late 1890s by the same Italian mosaic workers who had been practicing the marble mosaic 
trade for a number of years earlier. Terrazzo, however, would not gain acceptance for several decades. Most stone and concrete floors in the United States were marble mosaic until the mid-1920s, when American architects became aware of terrazzo's design potential. Terrazzo was well suited for the smooth, curvilinear designs of the Art Deco and Modern styles prevalent from the late 1920 s to 1940 s. Terrazzo soon overtook marble mosaic in popularity and came close to becoming a ubiquitous flooring material for public buildings and apartment buildings. ${ }^{77}$

The terrazzo manufacturing process adopted in the United States in the 1890s was different from traditional terrazzo techniques used in Venice. In the past, terrazzo workers placed or sprinkled the irregular bits of marble over a lime mastic and pounded them into it rather than mixing the marble granule with the cement as was practiced in the United States, and earlier-from the 1870s onward-in nearly all European countries. In fact, it was with the advent of Portland cement in the middle of the nineteenth century that terrazzo was developed as it is known today. Terrazzo floor surfaces are manufactured from a mixture of 70 percent or more marble chips and 30 percent or less Portland cement matrix over a concrete base. Decorative chips, typically marble, are chosen for their color and strength. The chips are graded by size, varying from number 1 (between $1 / 8$ and $1 / 4$ inches) to number 8 ( 1 to $1 \frac{1}{8}$ inches). A proportional mixture of sizes is most commonly used.

A factor that further influenced the spread of terrazzo all over the United States was the invention of the electric grinding and polishing machine. Before the early 1910s, the mosaic and terrazzo floor surfaces had to be ground down manually by workers using a galera, a piece of stone attached to a long handle of iron pipe that was pushed and pulled back and forth by a workman, gradually wearing down the terrazzo to a smooth, level surface. With the introduction of electric polishing for stone and terrazzo finishing, the terrazzo trade gained speed and accuracy, and overall costs were reduced. ${ }^{78}$ Likewise, technological advances positively affected terrazzo's popularity in the United States. Before 1919, terrazzo floors were laid in large monolithic slabs. This method presented problems in twentieth century office tower applications where terrazzo toppings were prone to cracking, particularly over structural elements. In 1919, the L. Del Turco and Brothers Company of Harrison, New Jersey, introduced a method to subdivide terrazzo surfaces with brass divider strips. "The innovation was adopted enthusiastically by the industry" wrote the developer of the method, Luigi (Louis) Del Turco, who came to New York from Sequals in $1907 .{ }^{79}$ Strips were used not only for the purpose of controlling cracks but also for decorative effects. The introduction of abrasive aggregates in terrazzo (such as Alundum) to render it non-slippery, has been called by Del Turco as "another improvement worthy of mention." 80

The American market thus began to request terrazzo workers more than mosaicists. The majority of them arrived in New York after World War I. In 1932, the architect Eugene Clute wrote that: "Most of the terrazzo workers in this country seem to have come originally from the Friuli province of Udine, 
a few hours from Venice." ${ }^{\circ 1}$ Prior to coming to the United States (namely before the Great War), almost all of them had been working in Europe, mostly in Germany, for terrazzo companies owned by their fellow countrymen; after the war, however, job conditions in Germany were highly unfavorable, and mosaic and terrazzo artisans were forced to migrate overseas and to other European countries. In the 1920s and 1930s, newly arrived terrazzo workers were often employed by Italians who had established their own companies in the early twentieth century. Other non-Italian American terrazzo companies also employed many Italians. These companies executed almost all the terrazzo floors in America's buildings during the interwar period. One of the most impressive of these terrazzo floors is situated in the New York Empire State Building. In the late 1920s, the De Paoli, Del Turco, and Foscato companies created a corporation to install 250,000 square feet of terrazzo in the corridors. This terrazzo flooring required about 1,250 yards of sand, 12,500 bags of cement, and 15,000 bags of marble chips. ${ }^{82}$

The Italian terrazzo companies, however, did not turn their backs on their ancient mosaic expertise. Bruno De Paoli and his firm of mosaic craftsmen in Long Island City installed the wonderful mosaics of Christ Church at 520 Park Avenue in New York City. And in 1935, Victor Foscato executed the much-admired Aztec Sun Stone mosaic in the Judy and Josh Weston Pavilion of the New York American Museum of Natural History at Columbus Avenue and West Seventy-ninth Street.

\section{A powerful network of firms: terrazzo and mosaic contractors organized}

For immigrant entrepreneurs, the initial market typically arises within the immigrant community. ${ }^{83}$ A large number of Italian entrepreneurial initiatives grew alongside the increasing number of Little Italies popping up in the United States, continually expanding and drawing on a clientele of fellow countrymen. In most cases the entrepreneurs came from within the community and catered to this community in particular. The commerce of ethnic products like pasta, wine, olive oil, and the catering for all fellow countrymen represented the most common entrepreneurial initiatives among the Italian businessmen. Conversely, terrazzo and mosaic workers had to deal with the tastes and needs of the American market and population, and their success is therefore unique in the history of Italian emigration to the United States.

As mentioned previously, the first Italian mosaic workers who came to the United States in the early 1880s were to be engaged by the New York decoration firm Herter Brothers. Several other mosaic workers arrived in New York during the same period and shortly after, thanks to the flow of information (letters) between Europe and the United States regarding employment possibilities in the city. In many cases, the mosaic workers who were already in New York sponsored tradesmen with whom they had worked in Europe to join them. This mechanism also secured a trustworthy skilled labor force for marble mosaic and terrazzo firms. In turn, the most adventurous of these mosaic and terrazzo 
workers started businesses of their own, first in New York and other northeastern American cities like Philadelphia, Boston, and Washington, DC, then later in the nearby Midwestern states of Kentucky, Tennessee, and West Virginia, and finally moving either further south or heading west. In fact, New York contractors sent artisans to other urban areas to affix pre-cut and set mosaics. If these employees saw market opportunities they often remained in the city to open a local branch of the business or begin their own business. ${ }^{84}$ In a sense, they became paradigms of self-made businessmen and built a powerful network of firms that dominated the market across America. Thus, Italian marble mosaic and then later terrazzo workers extended the trade throughout the country. To paraphrase Frank Thistlethwaite, who examined the migration of pottery artisans from Staffordshire to America (and wrote "[...] if we can trace the potters we can trace the industry"), pinpointing marble mosaic and terrazzo flooring in American building amounts to identifying a settlement of Italian marble mosaic and terrazzo workers. ${ }^{85}$

As the terrazzo industry began to expand, so did the need for an organization to support the growing number of installers. Costante (Gus) Cassini from Cavasso Nuovo in Friuli sent an invitation to twenty-seven terrazzo and mosaic contractors from all over the United States to meet in Chicago, in 1924, with the intent of creating the National Terrazzo and Mosaic Contractors Association, nowadays known as The National Terrazzo and Mosaic Association, Inc. (NTMA). ${ }^{86}$ Debate was raised in the association about the suitability of using the word "mosaic" in the title. In fact, in the mid-1920s, companies did considerably more terrazzo and less marble mosaic work. Twenty years earlier, the situation was exactly the opposite. Indeed, at the end of the 1800s or beginning 1900s contractors joined forces to create the New York-based The Mosaic Employers' Association, which became a member of the Building Trades' Employers' Association of Greater New York. ${ }^{87}$ Surviving information regarding the association is scarce, but it appears to be the first mosaic employers' organization in the United States. ${ }^{88}$

The membership of the National Terrazzo and Mosaic Contractors Association indicates not only the geographic changes in the spread of the trade, but also the intergenerational continuity within companies. In 1924, the old mosaic companies established in the 1880s and 1890s were, with only a few exceptions, no longer active. New companies established in the 1910s and early 1920s-from Minneapolis to Oklahoma, from Kansas City to Indianapolis, and from St. Louis to Chicago-represented the greater part of the new contractors association. By 1926, two years after its establishment, the membership of the National Terrazzo and Mosaic Contractors Association counted almost sixty firms, forty of which were owned and run by Italians. More than ten years later in 1938, of the ninety-three companies which made up the association, approximately sixty belonged to Italians or Italian Americans. At that point, the second generation of the company founders began to take control of their family enterprises. Nowadays, according to the registers of NTMA, Italian Americans control more than half of the mosaic 
and terrazzo companies throughout the United States, although the labor force is now comprised of only a minimal number of people of Italian origin. ${ }^{89}$

\section{Creative responses of a craftsmen group in a diachronic perspective}

The successful intergenerational continuity in business ownership, and the control of the trade over time by skilled marble mosaic and terrazzo workers from Friuli was secured by innovations adopted by artisans and companies. Creativity skills appear as a key factor that allowed these artisans to control the trade for such a long time, as well as to keep alive for centuries the popularity of marble mosaic and terrazzo (as regards to, e.g., ceramic tile or marble) among customers. The adoption of the "indirect method" for restoration and then for the industrial manufacturing of marble mosaic, ${ }^{90}$ the invention of a new method of laying mosaic, granolithic and similar floors, ${ }^{91}$ the development of the electric polishing machine, ${ }^{92}$ the invention of brass divider strips, ${ }^{93}$ the manufacturing of ornamental terrazzo, ${ }^{94}$ the development of epoxy terrazzo (a resin adopted in late 1960s that led to use of an unthinkable, boundless matrix for multicoloured patterns and designs) to the employment of computers to perform terrazzo designs, ${ }^{95}$ represent some of the steps of this innovative process. These examples of the "new thing" as a result of innovative action (the "new thing" that "need not be spectacular or of historic importance," in the words of Schumpeter) aligned the creative response of the marble mosaic and terrazzo entrepreneurs with the Schumpeterian entrepreneur whose "defining characteristic is simply the doing of new things or the doing of things that are already being done in a new way (innovation)." 96 Only by renovating the way of doing marble mosaic and terrazzo flooring did artisans secured its long-term persistence.

Moreover, what this craftsmanship experience shows is that their success was not merely a match between job market requirements and the skills offered by immigrants; instead, the marble mosaic and terrazzo workers brought to the fore knowledge and trade either on the whole or in part unknown in many of the new labor markets. In such a context the limited financial resources brought by these artisans appeared not to be an issue. It is important to point out that in the marble mosaic and terrazzo industry the need for capital to establish a company was not crucial in terms of the low investment required to purchase the tools and instruments necessary to execute a marble mosaic or a terrazzo. The technical and artisanal training that craftsmen brought with them was much more valuable than their financial resources.

Creative and innovative outcomes criss-crossed the shores of the Atlantic. In the late 1910s, the advantages of the use of the electric polishing machine, first developed in Germany, spread to the United States. A decade later, in the early 1930s, innovative techniques and new aesthetic trends in America, which was at that time the most important global market for terrazzo, reached the British terrazzo market. ${ }^{97}$ Peter Mazzioli, the son of the work manager at the Londonbased firm Diespeker \& Co., one of the most important terrazzo companies in the United Kingdom, remembers that: 
My father was in touch with Del Turco, Pellarin and other fellow countrymen from Sequals who were in the terrazzo business in the United States, so he was up-todate on the innovations in the American terrazzo sector. In the Twenties, in England we used Cassani polishing machines, which were made in Italy and had only one plate for polishing. In the following decade instead, Diespeker started to import some machines made in the United States that, compared to the Italian ones, had more plates for polishing and were more efficient. ${ }^{98}$

Friulian marble mosaic and terrazzo entrepreneurs took advantage of the network of family members and townspeople that extended from the European to the American shores. In fact, relationships between marble mosaic and terrazzo workers and entrepreneurs that had settled around the world were as strong as the bonds with their homeland. On the side of the intense relationship with the homeland, even during a very troublesome period like the Great Depression, the NTMA decided to support the Friuli Mosaic School in Spilimbergo with a yearly contribution (from 1929 to 1933) of $\$ 500.00$.

Within the Italian American marble mosaic and terrazzo industry a kind of labor hierarchy reflected the distinct skills resources and work traditions of the craftsmen: While the high-level workforce (the mechanics) were mainly from Friuli, helpers and polishers (both manual and non-manual) came chiefly from other Italian regions. ${ }^{99}$ Skilled and unskilled Italian laborers coexisted within the same industrial field. This is evidence of the fact that a highly segmented economic sector like the building industry, to which marble mosaic and terrazzo belong, does not accommodate only unskilled emigrant labourers but also skilled emigrant workers. Even though the two groups originated from the same country, skilled and unskilled workers did not come from the same Italian region. A national approach clearly falls short of contributing to defining the characteristics of the two groups, and their identity as well. As historian Marcus Lee Hansen well recognized "at any given moment the phenomenon of emigration is characterized, not by the nation as a whole, but by a comparatively restricted part of it, and when again it makes its appearance, though the participants are still listed as Germans or Italians, their origin was distinct."100 What the Italian case shows is that the heterogeneous emigrant experiences of the different local groups cannot be explained through the lens of a superficial homogeneous national background. Thus both marble mosaic and terrazzo mechanics showed a clannish loyalty to their craft, and a strong labor identity instead of an ethnic identity. In the United States, they firstly created unions, not national, regional, provincial, or village ethnic associations. However, it was the village, the province, or the regional area, rather than the national entity with which the group identified. In New York, e.g., a Friulian club was established only in 1929, and most of its founders worked in the marble mosaic and terrazzo industry. However, this regional association, which might be considered a regional loyalty reaction to the fascist attempts to "Italianize" the immigrant community, arose much later than the establishment of the 
mosaic mechanics union in the 1880s, and even after the creation of the employer's association in 1924. Skills rather than ethnicity seem a better key for interpreting marble mosaic and terrazzo workers' experience and assessing their success or failure.

\section{Conclusions}

The transplantation and diffusion in the United States of a typically Italian artisan heritage is to be credited to the immigrants themselves, proving that immigrants can be powerful conduits for the transfer of skills and knowledge. The marble mosaic and terrazzo workers' experience also demonstrates that a study into the diverse work experience of Italians and other immigrant groups who practiced artisan crafts in the United States, such as stonemasons, stonecutters, carpenters, masons, musicians, shoe-makers, cabinet-makers, glassmakers, pottery artisans, brewers - that despite scholarly works have been confined to the shadows of historiography - can surely open new research horizons. ${ }^{101}$ Job specializations or, in other words, "comparative advantages" of migrants (the various sorts of "capital" that migrants embody) often play a crucial role in the whole migratory experience, from the choice of migratory destinations to the length of the migrant experience. An in-depth examination and comparison of many artisanal and skilled migration experiences could lead to an interesting discussion on the commonly held view that migrants occupy the lower echelons of the job market. An assumption that can be challenged is the one that considers that immigrants become entrepreneurs in economic sectors that do not require high levels of specialization (e.g., neighborhood retailers, grocery stores), or in sectors that are fully interwoven into the fabric of the immigrant community since the immigrant entrepreneur exclusively meets the needs of the co-ethnics.

Many aspects support the story of the marble mosaic and terrazzo migration experience as a continuum. The story of Pellarin, Pasquali, and Foscato families, who were deeply involved in the art of terrazzo in seventeenth and eighteenth century Venice and in nineteenth and twentieth century North America, demonstrates the unusual perpetuation of a craft across several generations, as well as the extraordinary control of the trade by the same (migrant) families from the seventeenth and eighteenth to twentieth centuries. There is no evidence of such an extended duration of family craftsmanship across wide geographical areas and economic contexts: A diachronic perspective thus appears crucial in order to understand the complex structure of this skilled migration experience.

A marked long-lasting organizational approach seems to distinguish the marble mosaic and terrazzo workers' experience: Attempts to secure standards and to protect the interests of members guaranteed by the craft-guild in sixteenth century Venice, developed into a union arrangement in nineteenth century America but also in a trade association later on. The marble mosaic and terrazzo workers' strong tendency to become entrepreneurs over time 
might be explained by a consolidated tradition that goes back to seventeenth century Venice. This outcome is related not only to the guild system but specifically to its breaking up and the ensuing entrepreneurial process that encouraged the more talented and skilled terrazzo masters to embrace entrepreneurship. The immigrant's tendency toward self-employment induced by a blocked upward mobility in the host country, as is theorized by some scholars, ${ }^{102}$ does not really explain the marble mosaic and terrazzo entrepreneurial experiences. The largely assumed predisposition toward business does not seem to be a natural, general, and overwhelming feature of immigrants themselves, unless we consider the socio-economic and labor background characteristics of each migrant group. In many artisan migration experiences, only a long-term perspective, a historical reconstruction of the individual, familial, and villager migration patterns might highlight the predisposition to become (or even not become) an entrepreneur. The importance of the study of these entrepreneurial processes supports Joseph A. Schumpeter's assertion that: "Cumulation of carefully analyzed historical cases is the best means of shedding light [...], of supplying the theorist with strategic assumptions, and banishing slogans." ${ }^{.103}$ The research agenda prompts scholars to study the rich variety of immaterial skills and knowledge heritage transferred to the United States by migrants.

The lives and fortunes of the New York sample mentioned in this paper probably weighed in favor of those who succeeded, but this paper is far from being a celebratory narrative. By further piecing together information and evidence from miscellaneous sources it will be possible to trace the experiences and works of artisans who crossed the Atlantic to practice their trade and transfer a knowledge heritage to North America. Many aspects of the contribution offered by historical (and contemporary) skilled craft workers in the United States are still unknown. Further investigation and research may shed light on other unexplored experiences in the history of immigration to North America.

\section{Acknowledgement}

I wish to acknowledge the invaluable comments of the two anonymous reviewers, who contributed to ameliorate the final version of the article. A special thanks goes to Simone Battiston for his feedback and suggestions on the draft. Moreover, I am in debt to The Italian Academy for Advanced Studies in America at Columbia University, which granted me an annual fellowship allowing me to do research in New York City. A "short term fellowship" from the Winterthur Museum, Garden, \& Library also allowed me to consult the Herter Brothers papers at the Winterthur Museum, Winterthur, Delaware.

\section{NOTES}

1. Simone Battiston and Javier P. Grossutti, "When Arts and Crafts Education Meets Fascism: The Friuli Mosaic School, 1922-1943," History of Education 48 (2019): 751-68. 
2. Ken Fones-Wolf, "Transatlantic Craft Migrations and Transnational Spaces: Belgian Window Glass Workers in America, 1880-1920," Labor History, 45 (2004): 299-321; Bill Jones and Ronald L. Lewis, "Gender and Transnationality among Welsh Tin-plate Workers in Pittsburgh: The Hattie Williams Affair, 1895," Labor History, 48 (2007): 175-194; W. Walker Hanlon, "Skilled Immigrants and American Industrialization: Lessons from Newport News Shipyard," Business History Review 92 (2018): 605-32.

3. Manuela Farneti, Glossario tecnico-storico del mosaico. Technical-Historical Glossary of Mosaic Art. Con una breve storia del mosaico. With an Historical Survey of Mosaic Art (Ravenna, 1993), 49.

4. Carlo Bertelli, "Rinascimento del mosaico," in Il mosaico, ed. Carlo Bertelli (Milano, 1998), 229-30.

5. The Bianchini's story was described in George Sand's novel Les maîtres mosaïstes first published in 1838; see George Sand, Les maîtres mosaüstes, introduction by H. Lavagne (Paris 1993), 5-42; see also Ettore Merkel, "La mosaïque à Venise, de la renaissance au XIXe siècle," in Mosaïque. Trésor de la latinité des origines à nos jours, ed. Henri Lavagne, Élisabeth de Balanda, and Armando Uribe Echeverría (Quetigny, 2000), 370.

6. Valeria Cacciatori, "I pavimenti alla veneziana. Storia ed evoluzione artistica," in I pavimenti alla veneziana, ed. Lorenzo Lazzarini (Verona, 2008), 32.

7. Consiglio di Dieci, Comuni, February 9, 1582 more veneto (=1583), registro 36, carta 185 verso, Archivio di Stato di Venezia (Venice State Archive, hereafter cited as ASV),

8. Mariegola de terrazzeri, November 30, 1587, Cl. IV 223, Museo Correr, Venice.

9. Mariegola de terrazzeri, September 13, 1586, Cl. IV 223, Museo Correr, Venice.

10. On the role of guilds in Venice see Frederic C. Lane, Venice, a maritime republic (Baltimore, 1973), 315-21.

11. Terry Sammartini, Decorative floors of Venice (London, 2000), 20.

12. Fernand Braudel, Venezia (Bologna, 2013), 80.

13. Giovanni Caniato and Michela Dal Borgo, "Arte dei Terazzeri," in Le arti edili a Venezia, eds. Giovanni Caniato, and Michela Dal Borgo (Roma 1990), 155.

14. Caniato, and Dal Borgo, "Arte dei Terazzeri," 155-7.

15. Ibid., 20.

16. Capucine Lemaître, La conservation des mosä̈ques. Découverte et sauvegarde d'un patrimoine (France 1800-1914) (Rennes, 2008), 125-239 (particularly 129-92).

17. Jean-Luc de Ochandiano, Lyon à l'italienne. Deux siècles de présence italienne dans l'agglomération lyonnaise (Lyon, 2013), 33-34; Lemaître, La conservation des mosaïques, $164-5$.

18. François Loyer and Hélène Guéné, "Paris et le renouveau de la mosaïque au XIXe siècle," in Mosaïque. Trésor de la latinité, 386.

19. Edouard Gerspach, La Mosaïque (Paris, 1881), 228.

20. Rudolph J. Vecoli, "The Italian Diaspora, 1876-1976," in The Cambridge Survey of World Migration, ed. R. Cohen (Cambridge, 1995), 118.

21. Frank Thistlethwaite, "Migration from Europe Overseas in the Nineteenth and Twentieth Centuries," in A Century of European Migrations, 1830-1930, ed. Rudolph J. Vecoli, and Suzanne M. Sinke (Urbana and Chicago, IL, 1991), 29-30.

22. Robert F. Foerster, The Italian Emigration of Our Times (Cambridge, 1924 [1919]), 123.

23. Ibid.

24. Ibid., 124.

25. Immigration Commission, Reports of the Immigration Commission. Emigration Conditions in Europe (Washington, DC, 1911), 12.

26. Foerster, The Italian Emigration, 327; Robert F. Harney, "The Padrone and the Immigrant," The Canadian Review of American Studies V (1974) 101-18. At the earliest stage in Italian immigration "the padrone was the agent of the contractor or manufacturer. Laborers were demanded, and he acted simply as the agent in supplying specific demands [...] Under this early system there were numerous ways in which the padrone could make money [through e.g.] a commission from the men as well as from the contractor for furnishing the men, and commission on their passage," Industrial Commission, Reports on Immigration, v. XV (Washington, DC, 1901), 431.

27. Industrial Commission, Final Report of the Industrial Commission, v. XIX (Washington, DC, 1902), 961. 
28. Rudolph J. Vecoli. "The Italian Immigrants in the United States Labor Movement from 1880 to 1929," in Gli italiani fuori d'Italia, Gli emigrati italiani nei movimenti operai dei paesi d'adozione (1880-1940), ed. Bruno Bezza (Milano, 1983), 259.

29. Edwin Fenton, Immigrants and Unions. A Case Study. Italians and American Labor, 1870-1920 (New York, 1957), 378.

30. Ibid., 10.

31. Vecoli, "The Italian Immigrants in the United States," 262.

32. "The Italian as a Building Laborer," Real Estate Record and Builders Guide, June 10, $1893,904$.

33. Industrial Commission, Reports on Immigration, v. XV (Washington, DC, 1901), 474.

34. Foerster, The Italian Emigration, 352.

35. Javier P. Grossutti, "In the Hands of the Italians: Friulian Mosaic and Terrazzo Workers in London," in The Friulian Language: Identity, Migration, Culture, ed. Rosa Mucignat (London, 2014), 105-6.

36. William H. Burke, A Short History of Marble Mosaic Pavements and of the Events Connected with their Modern Revival (n.p. 189-), 10.

37. Undoubtedly, William Henry Burke knew The Herter Brothers firm, and probably met its German owners, too. In the early 1870s, Christian Herter visited London, Manchester, and Birmingham, in a time when England "was emerging as the world's leader in a movement dedicated to bringing truthful, well-crafted, 'moral' designs to a larger audience," Katherine S. Howe, "An Introduction to The Herter Brothers," in Herter Brothers. Furniture and Interiors for a Gilded Age, eds. Katherine S. Howe, Alice Cooney Frelinghuysen, and Catherine Hoover Voorsanger (Houston, 1994), 49-50.

38. Immigration Commission, Reports of the Immigration Commission. Emigration Conditions in Europe, 61.

39. Ibid., 60.

40. Thistlethwaite, "Migration from Europe Overseas," 30.

41. Howe, "An Introduction to The Herter Brothers," 53-55. 13.

42. Edward Strahan, Mr. Vanderbilt's House and Collection, v. 1 (New York, 1883-1884),

43. Herter Brothers Business Papers, col. 93, vol. 20, "Time book," 1901-1903. Joseph Downs Collection of Manuscripts and Printed Ephemera, The Winterthur Library, Del. These papers deal with the period between 1895 and 1907: records related to the period from the foundation of the company in 1865 to early 1890s are missing. On German cabinetmakers employed by the Herter Brothers see Catherine Hoover Voorsanger, "From the Bowery to Broadway. The Herter Brothers and the New York Furniture Trade," in Herter Brothers. Furniture and Interiors, eds. Howe, Cooney Frelinghuysen, and Hoover Voorsanger, 56-8.

44. Herter Brothers Business Papers, col. 93, box 25 (Pay roll factory and store), Joseph Downs Collection of Manuscripts and Printed Ephemera, The Winterthur Library, Del.

45. Grace Palladino, Skilled Hands, Strong Spirits. A Century of Building Trades History (Ithaca, NY, and London, 2005), 14.

46. John R. Commons, "The New York Building Trades," in Trade Unionism and Labor Problems, ed. John R. Commons (Boston, 1905), 66. On the contracting system see also William Haber, Industrial Relations in the Building Industry (Cambridge, MA, 1930), 15-48, 49-65.

47. The Venetian Marble Mosaic Art. Co to Bernard R. Green Esq. Office of Building of Library of Congress, June 13, 1896, box 87, Manuscript Division, Buildings and Grounds, Subseries 1, Manuscript Division, Library of Congress, Washington, DC.

48. The Art Amateur (April 1890): 104.

49. Ibid.

50. The American Architect and Building News, October 6, 1886, III.

51. The American Architect and Building News, June 4, 1898, 2.

52. Terrazzo and Old Mosaics. Fiftieth Anniversary Italian Marble Mosaic Company, 1942 (company brochure).

53. "New York Topics," Worcester Daily Spy, March 31, 1889, 2.

54. Ibid.

55. Richard Guy Wilson, "Architecture and the Reinterpretation of the Past in the American Renaissance," Winterthur Portfolio 18 (1983): 75. 
56. Howe, "An Introduction to The Herter Brothers," 46.

57. Bulletin of the United States Bureau of Labor Statistics, Miscellaneous Series, Handbook of American Trade-Unions, 506, November 1929, 21.

58. Ibid., 42.

59. Federal Writers' Project, The Italians of New York (New York, 1939), 161; Fenton, Immigrants and Unions, 382.

60. Ibid., 381.

61. Ibid., 382.

62. On technical changes in construction methods and mechanization of building operations see Haber, Industrial Relations, 15-48.

63. "Organized Labor. Weekly Meetings of the Central Labor Union," The Workmen's Advocate, December 28, 1889, 1.

64. "Organized Labor. Weekly Meetings of the Central Labor Union," The Workmen's Advocate, October 11, 1890, 1.

65. "Labor's Grand Showing. Ten Thousand Organized Toilers in the Central Labor Union Parade," The New York Herald, September 8, 1891, 3; "Many Unions on Parade," The New York Times, September 8, 1891, 3.

66. "Parliaments of Labor. Weekly Transactions of the Local Central Bodies," The Workmen's Advocate, April 24, 1890, 2; "Parliaments of Labor. Weekly Transactions of the Local Central Bodies," The Workmen's Advocate, November 13, 1890, 2.

67. Fenton, Immigrants and Unions, 383.

68. “Mosaic Workers' Grievances,” The New York Times, December 4, 1892, 8.

69. Picture of the board of delegates of the Building Trades of New York 1897, box OS 006, Building Trades Employers' Association Records WAG. 196, Elmer Holmes Bobst Library, Tamiment Library and Robert F. Wagner Labor Archive, New York City; "Anthony Tramontin," The Art of Mosaics and Terrazzo, V (Winter 1935): 7, 10.

70. "The Army of the Unemployed," Chicago Daily Tribune, August 6, 1893, 10.

71. "Building Trades Disturbed. Carpenters, Mosaic Workers and Tile Layers Begin Strikes," New York Herald, January 4, 1896, 5.

72. "Conciliation and Arbitration in the Building Trades of Greater New York," Bulletin of the United States Bureau of Labor Statistics, 124, June 16, 1913, 22.

73. Ibid., 26.

74. Form of Application for a Charter to the Bricklayers, Masons and Plasterers' International Union of America, October 25, 1919, International Union of Bricklayers \& Allied Craftworkers Archives, Washington, DC. Harry C. Bates, author of a history of the Bricklayers, Masons and Plasterers' International Union of America, provides no information on the New York mosaic worker's union application, Bricklayers' Century of Craftsmanship, (Washington, DC, 1955).

75. Mosaic and Terrazzo Workers Association records, Museo Lavoro ed Emigrazione, Cavasso Nuovo (Italy).

76. Population schedules, 1880, and 1890 Census of the United States, New York City, Eigteenth and Twenty-first Wards classified with relation to the native country and region of the individuals.

77. Walker C. Johnson, "Terrazzo," in Twentieth-Century Building Materials. History and Conservation, ed. Thomas C. Jester (Washington, DC, 1995), 237.

78. In Germany, where terrazzo was well-known even in the 1870 s and 1880 s, electric polishing machines were used as early as 1910, an evidence of the vitality of the business sector in this country. The electric polishing machine, first used by the Friulian entrepreneur Marco Rosa in Mannheim, was considered a sort of "revolution": Luigi Bossi, "Per i lavoranti in terrazzo. Una rivoluzione," L'Emigrante. Bollettino dei Segretariati dell'Emigrazione di Udine, Belluno e Vittorio, VII (1912): 3.

79. Louis Del Turco, "A Brief History of Mosaic Floors and Terrazzo Work," The Art of Mosaics and Terrazzo, II (March 1931): 16.

80. Ibid., 17.

81. Eugene Clute, "Modern Craftsmanship in Terrazzo," Architecture (March 1932): 13742.

82. Carol Willis, Building the Empire State (New York, 1998), 64.

83. Roger Waldinger, Howard Aldrich, and Robin Ward, "Opportunities, Group Characteristics and Strategies," in Ethnic Entrepreneurs. Immigrant Business in Industrial 
Societies, ed. Roger Waldinger, Howard Aldrich, and Robin Ward (Newbury Park, London, and New Delhi, 2006), 21-22.

84. John Zucchi, "Immigrant Friulani in North America," in Italian Immigrants in Rural and Small Town America, Essays from the Fourteenth Annual Conference of the American Italian Historical Association, ed. Rudolph J. Vecoli (New York, 1987), 62-71.

85. Frank Thistlethwaite, "The Atlantic Migration of the Pottery Industry," The Economic History Review, New Series, 11 (November 1958): 265.

86. The National Terrazzo and Mosaic Contractors Association, Minutes of the Organization (Chicago, 1924), 3.

87. The Building Trades' Employers' Association was formed in New York City in May 1903. It was a federation of the existing building trades associations, and included individual members as well: The Building Trades Employers' Association, The Handbook of the Building Trades Employers' Association of the City of New York (New York, 1921), 5-7; Haber, Industrial Relations, 348-51.

88. Minutes of Convention held Tuesday, March 21, 1905-in rooms of-Building Trades Employers' Association for the purpose of Amending the present Arbitration Plan, p. 15, box 36, Building Trades Employers' Association Records WAG. 196, Elmer Holmes Bobst Library, Tamiment Library and Robert F. Wagner Labor Archive, New York City. TX.

89. The National Terrazzo and Mosaic Association, Inc. (NTMA) records, Fredericksburg,

90. See, e.g., the "extraction and laying method of ancient mosaics without modifying it" (Système d'extraction et pose sans alteration des mosaïques antiques) patented by Gian Domenico Facchina in 1858.

91. See, e.g., United States Patent Office, Method of laying mosaic, granolithic and similar floors invented by Peter (Pietro) Pellarin of Detroit, MI. No. 898.001. Patented September 8, 1908.

92. See, e.g., United States Patent Office, Polishing Machine invented by Antonio G. Ferrarini of Chicago, Ill. No. 1.180.992. Patented April 25, 1916.

93. See, e.g., United States Patent Office, Dividing strip for cementitious floors invented by Louis (Luigi) Del Turco of Newark, NJ. No. 1.368.374. Patented February 15, 1921; Unites States Patent Office, Divider for cementitious floors invented by Louis Del Turco of Newark, NJ. No. 1.401.590. Patented December 27, 1921; United States Patent Office, Terrazzo flooring and method of laying terrazzo invented by Louis Del Turco of Newark, NJ. Original No. 1.368.374. Application for reissue filed May 23, 1922, Serial No. 563.103.

94. See, e.g., United States Patent Office, Ornamental terrazzo invented by Romano De Paoli of Roxbury, Mass. No. 2.835.996. Patented May 27, 1958.

95. Katia Porro, "Seeking Truth in Terrazzo: Digital Practices and Traditional Crafts," The Journal of Modern Craft 11 (2018): 219-31.

96. Joseph A. Schumpeter, "The Creative Response in Economic History," The Journal of Economic History 7 (1947): 151.

97. Grossutti, "In the Hands of the Italians," 117.

98. Ibid., 116-7.

99. This labor division in marble mosaic and terrazzo industry was seen also among marble mosaic and terrazzo artisans that operated in London; Javier P. Grossutti, "Italian Artisans of marble mosaic in the United Kingdom: migrants as conveyors of skills and knowledge in a transnational perspective," in Migrants: Art, Artists, Materials and Ideas Crossing Borders, eds. Lucy Wrapson et al. (London, 2019), 37.

100. Marcus Lee Hansen, The Immigrant in American History, ed. Arthur Schlesinger (Cambridge, MA, 1941), 191-2. The research approach largely continues to consider Italian migrants as part of a national undifferentiated migration flow. "Seen through a magnifying glass, this undifferentiated mass surface breaks down into a honeycomb of innumerable particular cells, districts, villages, towns, each with an individual reaction or lack of it to the pull of migration [...] Only when we examine such districts and townships, and trace the fortunes of their native sons, do we begin to understand the true anatomy of migration" pointed out Thistlethwaite, "Migration from Europe Overseas," 28.

101. On Italians workmen involved in artisan crafts in the United States, see, e.g., Regina Soria, Fratelli lontani. Il contributo degli artisti italiani all'identità degli Stati Uniti (1776-1945) (Napoli, 1997); Patrizia Audenino, "The Paths of the Trade: Italian Stonemasons in the 
United States," International Migration Review, 20 (1986): 779-5; Jayson Kerr Dobney, Guitar Heroes. Legendary Craftsmen from Italy to New York (New York, 2011).

102. For an overview of the main approaches see, e.g., Ivan Light, Ethnic Enterprise in America (Berkeley, CA, 1972); Waldinger, Aldrich, and Ward, "Opportunities, Group Characteristics," 32, 44; Alejandro Portes and Jessica Yiu, "Entrepreneurship, transnationalism, and development," Migration Studies 1 (2013): 75-95.

103. Schumpeter, "The Creative Response," 155-6. On the Schumpeter's calling for the extensive use of historical methods in the study of entrepreneurship see Geoffrey Jones, and R. Daniel Wadhwani, Schumpeter's Plea: Rediscovering History and Relevance in the Study of Entrepreneurship, Harvard Business School Working Paper Number: 06-036, 2006, http:// www.hbs.edu/faculty/Publication \%20Files/06-036.pdf. 